\title{
The effect of emotional labor levels on the attitudes of neonatal intensive care nurses towards palliative care
}

\section{Yenidoğan yoğun bakım hemşirelerinin duygusal emek düzeylerinin palyatif bakıma yönelik tutumlarına etkisi}

\author{
DBeyzanur Erel, @Esra Tural Büyük \\ Ondokuz Mayıs University, Faculty of Health Sciences, Department of Pediatric Nursing, Samsun, Turkey
}

Cite this article as / Bu makaleye atıf için: Erel B, Tural Büyük E. The effect of emotional labor levels on the attitudes of neonatal intensive care nurses towards palliative care. J Med Palliat Care 2021; 2(2): 40-46.

\begin{abstract}
Introduction: Neonatal nurses, who experience many challenging emotions while providing palliative care, must empathize with the patient and their family, maintain control, act neutrally and be understanding during the care process. Emotional labor levels of the neonatal nurses such as managing and being aware of their emotions, taking on determined roles, and acting according to predetermined standards even though they have much different feelings, are important in the palliative care process. The aim of this study is to determine the effect of emotional labor levels of neonatal nurses on their attitudes towards palliative care.

Material and Method: This study was a correlational, cross-sectional and descriptive design and was conducted with 75 nurses employed in the neonatal intensive care units (NICU) in a provincial center in the north of Turkey. The data of the study were collected by using Personal Information Form, Emotional Labor Scale (ELS) and Neonatal Palliative Care Attitude Scale (NPCAS).The data were analyzed with SPSS 23. Descriptive statistics, non-parametric tests and Spearman correlation analysis were used in the evaluation of the data.

Results: Among the NICU nurses, who participated in the study, $61.3 \%$ stated that they did not receive training in palliative care, and $84 \%$ did not find their knowledge about palliative care sufficient. A statistically significant and negative correlation was found between the surface acting sub-dimension of ELS and the resources sub-dimension of NPCAS ( $\mathrm{p}=0.046)$; and a statistically significant and positive correlation was found between expression of naturally-felt emotions sub-dimension of ELS and the clinicians sub-dimension of NPCAS ( $\mathrm{p}=0.005)$.

Conclusion: In the present study, where the factors affecting the emotional labor levels of nurses were examined, it was observed that nurses suppressed their real emotions and acted superficially while providing the palliative care services. Despite the fact that the nurses displayed a positive attitude towards recognizing the neonatal palliative care practices and acting in cooperation, they stated that the institutional support was not sufficient.
\end{abstract}

Keywords: Nurse, newborn emotional labor, palliative care

\section{ÖZ}

Amaç: Palyatif bakım hizmeti sunarken birçok zorlayıcı duygu deneyimleyen yenidoğan hemşireleri, bakım sürecinde hasta ve ailesi ile empati kurması, kontrollü, yansız ve anlayışlı olması gerekmektedir. Yenidoğan yoğun bakım hemşirelerinin duygularını yönetip farkında olması, belirlenmiş roller üstlenmesi ve çok daha farklı hisler içinde olsalar da önceden belirlenmiş standartlara göre davranması gibi sarf ettikleri duygusal emek düzeyleri, palyatif bakım sürecinde önem taşımaktadır. Bu araştırmanın amacı yenidoğan yoğun bakım hemşirelerinin duygusal emek düzeylerinin palyatif bakıma yönelik tutumlarına etkisinin belirlenmesidir.

Gereç ve Yöntem: Kesitsel ve tanımlayıcı tipte olan araștırma Türkiye’nin kuzeyindeki bir il merkezinde yenidoğan yoğun bakım ünitelerinde (YYBÜ) çalıșan 75 hemşire ile gerçekleştirildi. Araştırma verileri Kişisel bilgi formu, Duygusal Emek Ölçeği (DEÖ) ve Yenidoğan Palyatif Bakım Tutum Ölçeği (YPBTÖ) kullanılarak toplanmıștır. Veriler SPSS 23 ile analiz edilmiş olup, verilerin değerlendirilmesinde tanımlayıcı istatistikler, non parametrik testler ve Spearman korelasyon analizi kullanılmıştır.

Bulgular: Araştırmaya katılan YYBÜ hemşirelerinin \%61,3’ü palyatif bakım konusunda eğitim almadıklarını ve \%84’ü palyatif bakım konusunda bilgilerini yeterli bulmadıklarını belirtmişlerdir. DEÖ'nün yüzeysel davranış alt boyutu ile YPBTÖ’nün kaynaklar alt boyutu arasında negatif yönde ( $\mathrm{p}=0,046)$, gerçek duyguları bastırma alt boyutu ile YPBTÖ’nün klinik alt boyutu arasında pozitif yönde istatistiksel olarak anlamlı bir ilişki bulunmuştur ( $\mathrm{p}=0,005)$.

Sonuç: Hemşirelerin duygusal emek düzeylerinin etkileyen faktörlere yönelik yapılan bu araştırmada, hemşirelerin palyatif bakım hizmeti sunarken gerçek duygularını bastırdığı ve yüzeyel davranış sergilediği görülmüştür. Hemşireler yenidoğan palyatif bakım uygulamalarını tanıma ve işbirliği içinde olma yönünde olumlu tutum sergilemelerine rağmen, sağlanan kurumsal desteğin yeterli olmadığını belirtmişlerdir.

Anahtar Kelimeler: Hemşire, yenidoğan, duygusal emek, palyatif bakım 


\section{INTRODUCTION}

Medical and technological developments have led to an increase in the survival rates in neonatal intensive care units as well as the number of newborns in need of palliative care (1-3). Nurses are responsible for the care of the newborns in these units. They are the closest health care professionals to the dying newborn, interacting directly with the patient and their family $(2,4)$. Studies have demonstrated that the care provided to the patients in the terminal period or for the dying patients affected the nurses negatively. Particularly, nurses have more difficulty in coping when the dying patient is a newborn; and the negative attitude decreases the quality of the care given to the patient (3-6). Nurses, who provide palliative care, go through different emotional processes, causing them to experience feelings such as anger, anxiety, stress, depression, helplessness, failure, inadequacy and denial $(2,4,5,7)$. During the care process, neonatal nurses, who experience many challenging emotions, have to empathize with patients and their relatives, be controlled, objective and understanding, manage and be aware of their emotions, undertake specified roles, and act according to predetermined standards, even when they have different emotions (3-5). Accordingly, the nurses with high workloads in palliative care units, who encounter intense human relationships and go through many emotional processes, make an extra effort and display emotional labor while displaying the attitudes and emotions expected of them (8-13). In palliative care, the increase in the conflict between the emotions felt and expressed by the nurses also increases the level of emotional labor spent while caring for patients with both physical and mental labor $(4,12,14,15)$. Studies have demonstrated that the emotional labor behaviors of the nurses are affected by the personal and professional factors (age, education, duration of professional experience, department, the number of patients they care for, etc.). The nurses suppress their real emotions and exhibit surface acts, thereby spending greater emotional labor $(7,12,16,18$ 20 ). For these reasons, emotional labor behaviors of nurses providing palliative care services have a special importance in terms of patient relations. According to the literature review performed in Turkey, there is no study examining the effect of the emotional labor levels on the attitudes of neonatal nurses towards palliative care. Therefore, it is believed that this study would contribute to increasing the quality of nursing care.

The aim of this study is to determine the effect of emotional labor levels on the attitudes of neonatal nurses towards palliative care.

\section{Research Questions}

1. What are the emotional labor levels of neonatal nurses?

2. What are the attitudes of neonatal nurses towards palliative care?

3. Is there a relationship between the emotional labor level of neonatal nurses and their attitudes towards neonatal palliative care?

\section{MATERIAL AND METHOD}

Permission was obtained from each institution where the study was conducted, and approval was obtained from the Ethics Committee of the Faculty of Medicine, Ondokuz Mayıs University (Date: 26.12.2019, Decision No: B.30.2.ODM.0.20.08/828-1043). All procedures were performed adhered to the ethical rules and the Helsinki Declaration of Principles.

\section{Design}

This study has a correlational, cross-sectional and descriptive design. It was conducted between January 2020 and December 2019 in a university and a state hospital located in a province in the North of Turkey.

\section{Population and Sample}

The population of the study consisted of 96 nurses employed in the neonatal intensive care unit of a state and a university hospital located in a provincial center in the north of Turkey. When determining the size of the sample, it was aimed to reach the whole universe without selecting the sample from the population. In this regard, a total of 75 nurses participated in our study, reaching the $78 \%$ of the population.

The criteria for inclusion of the nurses consisted of minimum one year of experience in their current unit and provision of newborn intensive palliative care (secondary and tertiary care units). The exclusion criteria for the nurses included employment in healthy neonatal follow-up units within the scope of outpatient clinic service, refusing to participate in the study, being on leave and/or sick leave at the time of the study, filling in the forms incompletely.

\section{Data Collection Tools}

Personal Information Form, Emotional Labor Scale (ELS) and Neonatal Palliative Care Attitude Scale (NPCAS) were used as data collection tools in the study.

\section{Personal Information Form}

This form was developed by the researchers with the aim of identifying the sociodemographic and professional characteristics of the nurses such as age, marital status, education level, institution, position, professional experience, weekly working time and number of newborns they cared for. The form, which consisted of 10 questions, also aimed to determine the whether they received any training on palliative care and whether they found their knowledge on this subject sufficient. 


\section{Emotional Labor Scalen (ELS)}

It is a 5-Point Likert-Type Scale consisting of 11 items. It was developed by Grandey (21) based on the study of Brotheridge and Lee (22) and translated into Turkish by Oral and Köse (23). The scale has four dimensions. These four dimensions were named as surface acting, deep acting, emotion termination and expression of naturally-felt emotions. Each dimension of the scale is evaluated separately, and the total score of the scale is not calculated. In terms of the evaluation of the scale, the higher mean scores obtained from the sub-dimensions indicate more frequent display of the emotional labor behavior related to that sub-dimension. In the study conducted in our country, the mean Cronbach's Alpha values of the scale were calculated as 0.76 for surface acting, 0.73 for emotion termination, 0.60 for deep acting and 0.63 for expression of naturally-felt emotions. [23] In the present study, the Cronbach's Alpha coefficient was calculated as 0.662 for surface acting, 0.637 for deep acting, 0.625 for emotion termination, 0.556 for expression of naturally-felt emotions.

\section{Neonatal Palliative Care Attitude Scale-NPCAS}

This scale was developed by Kain et al. (24) in order to determine the factors that neonatal nurses perceived as obstacles and facilitators within palliative care. The scale was translated into Turkish by Akay (2). It is a five-point Likert-type scale consisting of 26 questions. The scale consists of three sub-dimensions including organization $(5,8,15,16,19)$, resources $(6,7,13,14,24)$ and clinicians $(20,21)$. Organization sub-dimension measures the facilitators or barriers found in the environment of the clinic where nurses work for palliative care practices. Resources subdimension measures the availability of resources that support the palliative care model, such as the appropriate environment, medical staff, sufficient time for parents, counseling, and appropriate policies and guidelines regarding neonatal palliative care. Clinicians sub-dimension measures the moral/ethical concerns of nurses caused by technological necessities and demands of the parents. The high score obtained from the sub-dimensions of the scale indicates that the individual has a high level of positive attitude towards the relevant sub-dimension. As a result of the adaptation study, the Cronbach's Alpha value of the scale was 0.692 for the organization sub-dimension, 0.710 for the references sub-dimension, and 0.680 for the clinicians sub-dimension (2). In the present study, the Cronbach's Alpha value was found as 0.595 for the organization sub-dimension, 0.796 for the references sub-dimension, and 0.652 for the clinicians subdimension.

\section{Statistical Analysis}

The data obtained from the study were evaluated in SPSS 23.0 program (SPSS Inc, ChicagoIl, USA). The frequencies and percentages of nurses were used to analyze their sociodemographic characteristics during data analysis. Firstly, the Kolmogorov-Smirnov test was used to determine whether the data was distributed normally. Number, percentage, mean, standard deviation and median were used as descriptive statistics; non parametric tests (Mann Whitney-U test, KruskalWallis test and Post Hoc test-Tamhane test) were used to analyze the data with non- normal distribution. Spearman correlation analysis was performed to investigate possible correlations between Emotional Labor Scale (ELS) and Neonatal Palliative Care Attitude Scale (NPCAS). For all the analyses, a $\mathrm{p}<0.05$ was considered to be statistically significant.

\section{RESULTS}

The findings about the distribution of sociodemographic characteristics of nurses are presented in Table 1. The mean age of the nurses was found to be $32.83 \pm 5.6$ ( $\min .23$, max. 46 ). It was found that $36 \%$ of the nurses were between the ages of $31-35,68 \%$ were married and $77.3 \%$ had a bachelor's degree. It was determined that $38.7 \%$ of the nurses had a professional experience of 12 years and above, $68 \%$ worked 40 hours a week, $57 \%$ provided care for 5-6 newborns per night, $97.3 \%$ were clinical nurses working in both day and night shifts. Looking at the educational backgrounds of the nurses regarding neonatal palliative care, $61.3 \%$ stated that they did not receive training in palliative care, and $84 \%$ did not find their knowledge about palliative care sufficient (Table 1).

The mean scores obtained by NICU nurses in the sub-dimensions of ELS were found to be $3.02 \pm 0.8$ for expression of naturally-felt emotions, $2.138 \pm 0.7$ for surface acting, $2.08 \pm 0.93$ for deep acting, and $1.97 \pm 0.67$ for emotion termination, respectively. The mean scores obtained from the sub-dimensions of NPCAS were found to be $3.317 \pm 0.501$ for organization, $2.350 \pm 0.558$ for clinicians, and 2.349 \pm 0.809 for resources, respectively (Table 2 ).

According to the results of the correlation analysis on ELS and NPCAS, a positive, weak and statistically significant relationship was found between the expression of naturally-felt emotions sub-dimension of ELS and the clinicians sub-dimension of NPCAS $(\mathrm{r}=0.324, \mathrm{p}=0.005)$. A negative, weak and statistically significant relationship was found between the surface acting sub-dimension of ELS and the resources subdimension of NPCAS ( $\mathrm{r}=0.231, \mathrm{p}=0.046)$ (Table 3). 
Table 1. Socio-demographic characteristics of neonatal nurses, and their educational background regarding palliative care $(n=75)$

\begin{tabular}{|c|c|c|c|}
\hline \multicolumn{2}{|l|}{ Characteristics } & \multirow{2}{*}{$\begin{array}{l}\mathbf{n} \\
10\end{array}$} & \multirow{2}{*}{$\begin{array}{c}\% \\
13.3\end{array}$} \\
\hline \multirow{4}{*}{$\begin{array}{l}\text { Mean age: } \\
32.83 \pm 5.58 \\
(\min 20, \max . \\
46)\end{array}$} & $20-25$ years of age & & \\
\hline & $26-30$ years of age & 17 & 22.7 \\
\hline & $31-35$ years of age & 27 & 36.0 \\
\hline & 36 years of age and over & 21 & 28.0 \\
\hline \multirow{2}{*}{ Marital status } & Married & 51 & 68.0 \\
\hline & Single & 24 & 32.0 \\
\hline \multirow{3}{*}{$\begin{array}{l}\text { Educational } \\
\text { background }\end{array}$} & High school + associate degree & 8 & 10.7 \\
\hline & Bachelor's degree & 58 & 77.3 \\
\hline & Master's Degree $+\mathrm{PhD}$ & 9 & 12.0 \\
\hline \multirow{4}{*}{$\begin{array}{l}\text { Professional } \\
\text { experience }\end{array}$} & $1-3$ years & 18 & 24.0 \\
\hline & 4-7 years & 12 & 16.0 \\
\hline & $8-11$ years & 16 & 21.3 \\
\hline & 12 years and more & 29 & 38.7 \\
\hline \multirow{2}{*}{$\begin{array}{l}\text { Position at the } \\
\text { institution }\end{array}$} & Nursing Supervisor & 2 & 2.7 \\
\hline & Clinical Nurse & 73 & 97.3 \\
\hline \multirow{2}{*}{$\begin{array}{l}\text { Weekly working } \\
\text { time }\end{array}$} & 40 hours & 51 & 68.0 \\
\hline & 48-56 hours & 24 & 32.0 \\
\hline \multirow{2}{*}{$\begin{array}{l}\text { Type of } \\
\text { employment in } \\
\text { the institution }\end{array}$} & Day shift only & 2 & 2.7 \\
\hline & Day + night shifts & 73 & 97.3 \\
\hline \multirow{2}{*}{$\begin{array}{l}\text { Number of } \\
\text { newborns cared } \\
\text { for during the } \\
\text { night shift }\end{array}$} & 3-4 newborns & 32 & 43.0 \\
\hline & 5-6 newborns & 43 & 57.0 \\
\hline \multirow{2}{*}{$\begin{array}{l}\text { Experience of in- } \\
\text { service training } \\
\text { on palliative care }\end{array}$} & Yes & 29 & 38.7 \\
\hline & No & 46 & 61.3 \\
\hline \multirow{2}{*}{$\begin{array}{l}\text { Finding the } \\
\text { knowledge about } \\
\text { palliative care } \\
\text { sufficient }\end{array}$} & Finds it sufficient & 12 & 16.0 \\
\hline & Finds it insufficient & 63 & 84.0 \\
\hline
\end{tabular}

Table 2. Mean scores obtained from the sub-dimensions of ELS and NPCAS

\begin{tabular}{|c|c|c|c|c|}
\hline & & $\overline{\mathbf{X}} \pm \mathrm{SD}$ & $\begin{array}{l}\text { Min.- } \\
\operatorname{Max}\end{array}$ & Median \\
\hline \multirow{4}{*}{$\begin{array}{l}\text { Sub- } \\
\text { dimensions } \\
\text { of ELS }\end{array}$} & $\begin{array}{l}\text { Expression of } \\
\text { naturally-felt emotions }\end{array}$ & $3.02 \pm 0.83$ & $1-5$ & 3.0 \\
\hline & Surface acting & $2.13 \pm 0.67$ & $1-3$ & 2.3 \\
\hline & Deep acting & $2.08 \pm 0.93$ & $1-4$ & 2.0 \\
\hline & Emotion termination & $1.96 \pm 0.67$ & $1-4$ & 1.7 \\
\hline \multirow{3}{*}{$\begin{array}{l}\text { Sub- } \\
\text { dimensions } \\
\text { of NPCAS }\end{array}$} & Organization & $3.31 \pm 0.50$ & $2-4$ & 3.2 \\
\hline & Clinicians & $2.350 \pm 0.55$ & $1-5$ & 2.4 \\
\hline & Resources & $2.349 \pm 0.80$ & $1-4$ & 2.5 \\
\hline$\overline{\mathrm{X}} \pm$ SD: Mean \pm & ndard Deviation & & & \\
\hline
\end{tabular}

\section{DISCUSSION}

In this study, which examined the emotional labor levels of neonatal intensive care unit (NICU) nurses on palliative care, has found that most of the nurses did not have any education about palliative care, did not find their knowledge sufficient on this subject. neonatal intensive care unit (NICU) nurses suppressed their real emotions while providing palliative care and behaved superficially. Besides, It was determined that they displayed a positive attitude towards knowing and cooperating with neonatal palliative care practices. neonatal intensive care unit (NICU) nurses stated that the institutional support provided to them was not sufficient. Also, it was found that as nurses' suppression of real emotions increased, clinicians displayed more positive attitudes towards palliative care in the sub-dimension, and as the state of displaying the emotion expected by the institution increased, attitude towards resources decreased.

In the study, the majority of the nurses stated that they did not receive in-service training on palliative care, and that they did not find their knowledge sufficient on this subject. Previous studies reported that the neonatal nurses had insufficient knowledge about palliative care, and they perceived this insufficiency as an obstacle to providing quality palliative care $(3,25,26)$. In some studies, it was found that the nurses employed in palliative care units had better levels of knowledge compared to the nurses working in other departments $(2,27)$. Palliative care is included in nursing education. Nonetheless, it is believed that the subject of palliative care for the newborn is not sufficiently included in both undergraduate education and in-service training; and that the content of the education is more oriented towards symptom management such as pain.

This study, it was observed that the neonatal nurses mostly suppressed their naturally-felt emotions and displayed surface acting (displaying the emotion that the institution expected) as the emotional labor (Table 2). This finding shows that nurses display the emotion expected by the institution while providing care to their patients, thereby suppressing the real emotions they feel. In some studies, it was observed that the nurses displayed surface acting and deep acting (trying to avoid displaying their own emotions) the most $(7,18,19)$. According to the studies

Table 3. Correlations between the sub-dimensions of ELS and NPCAS

\begin{tabular}{|c|c|c|c|c|c|c|}
\hline \multirow{3}{*}{ ELS } & \multicolumn{6}{|c|}{ NPCAS } \\
\hline & \multicolumn{2}{|c|}{ Organization } & \multicolumn{2}{|c|}{ Resources } & \multicolumn{2}{|c|}{$\underline{\text { Clinicians }}$} \\
\hline & $\mathbf{r}$ & $\mathbf{p}$ & $\mathbf{r}$ & $\mathbf{p}$ & $\mathbf{r}$ & $\mathbf{p}$ \\
\hline Expression of naturally-felt emotions & 0.155 & 0.185 & 0.148 & 0.206 & $0.324^{*}$ & 0.005 \\
\hline Surface acting & -0.070 & 0.553 & $-0.231^{\star}$ & 0.046 & 0.182 & 0.118 \\
\hline Deep acting & 0.167 & 0.152 & 0.074 & 0.222 & 0.217 & 0.185 \\
\hline Emotion termination & 0.143 & 0.222 & 0.058 & 0.618 & 0.119 & 0.206 \\
\hline
\end{tabular}


conducted with nurses responsible for palliative care services, witnessing death every day causes the nurses to be exposed to a lot of emotional pressure, to spend more emotional labor and to experience more lack of emotional support (28-30). Certain studies demonstrated that the emotional labor spent by the nurses could lead to personal and professional development, and that they would attain "a professional skill" in order to avoid long-term negativity $(29,31)$. Looking at the results of this study and the literature, it was found that the sub-dimensions of the emotional labor scale differed according to the study. It is believed that this may be due to the socio-demographic, personal and professional characteristics of the participants in studies conducted with nurses.

In the present study, it was determined that the negative attitude of nurses towards neonatal palliative care originated from the sub-dimension of resources (a tendency of insufficiency or a degree of disagreement regarding the environmental conditions, sufficient staff, sufficient time and the presence of certain policies). Previous studies reported that the obstacles encountered by the nurses during palliative care were the factors such as adverse environmental conditions, technological necessities, insufficient number of staff, ethical dilemmas and the lack of clinical guidelines to provide palliative care $(2,3,5,30)$. Unlike the study, it was determined in some studies that positive attitude towards palliative care stemmed from the sub-dimension of resources $(26,32)$. It is believed that this may be due to the difference in the resources of countries for neonatal palliative care.

In this study is the first study investigating the relationship between emotional labor levels and the attitudes of neonatal nurses towards palliative care. In the study, it was determined that as the behavior of nurses to suppress real emotions increased, they displayed more positive attitudes towards palliative care in the clinicians sub-dimension. Therefore, the study suggests that the technological obligations and moral/ethical concerns experienced by nurses regarding palliative care mostly cause them to suppress their actual feelings. In the previous studies, it was mentioned that nurses, who provided palliative care, learnt emotional management processes over time, recognized that acting as the institution expected of them (instead of actual emotions) might cause alienation of the self, tried to prevent grief by restricting the emotions, and this could conflict with their self-identities $(29,33)$. In a study conducted on the factors affecting the emotional labor of the neonatal nurses, it was observed that the institutional support provided to nurses was not sufficient. It was stated that the recognition of emotional labor at institutional levels helped encourage nurses to work, contributing indirectly to patient safety (4).
In the study, it was found that as the level of surface acting (displaying the emotion expected by the institution) increased, the attitudes towards resources (the dimension that measures institutional and individual opportunities related to palliative care) decreased. Therefore, it is believed that nurses perceive environmental factors as negative obstacles in providing palliative care services, since they display the emotions expected by the institutions. Due to the barriers in the health system, the insufficiency of human resources increases the workload of healthcare workers; therefore, the opportunities for nurses to provide palliative care are restricted $(26,34,35)$. Studies demonstrated that nurses providing palliative care often had difficulties in finding time and place to cope with grief, and encountered normative restrictions on expressing grief in the institution $(26,36,37)$. It is believed that emotional control is professional norm, and that the normative imperatives of emotional self-control in palliative care providers are idealized and shaped as a professional skill $(29,31)$. It was reported that the corporate culture influenced their perceptions of maintaining a "professional mood", and that palliative caregivers generally increased the pressure to suppress emotionality $(29,38)$. In addition, it was stated that a corporate culture normalizing emotional experiences and expression and providing time and space for nurses to benefit from the informal and formal support structures, thereby avoiding the examples of emotional formation $(32,39)$.

There are some limitations to the research. The first is, although the majority of contacted neonatal nurses participated in this study, the entire population could not be reached due to some nurses being sick and some being on a leave of absence. The second is that the participants' responses to data collection tools are based on their own opinions. The third is that emotional labor and attitudes of nurses can be affected by many mental factors (personality traits, additional psychiatric disorders, additional medical conditions, alcohol and substance use, etc.). Finally, the study is limited to sampling consisting only of nurses working in the North Anatolian region, and the findings cannot be generalized in terms of the entire country.

\section{CONCLUSION}

It was observed in the study that most of the nurses did not receive information about palliative care and did not find themselves sufficient in this subject. It was found that nurses spent emotional labor mostly in the form of suppressing naturally-felt emotions and surface acting. It was determined that the positive attitudes of the nurses towards palliative care was in the subdimensions of organization, clinicians and resources, respectively. Certain sociodemographic and occupational 
characteristics were found to be associated with ELS and NPCAS. It was found that there was a weak positive correlation between the expression of naturally-felt emotions sub-dimension of the ELS and the clinicians sub-dimension of NPCAS. In addition, there was a weak correlation between the surface acting sub-dimension of the ELS and the resources sub-dimension of NPCAS.

\section{Practice Implications}

In line with the results obtained from the study, neonatal nurses should be provided with training on emotional resilience, communication and emotional labor in order to prevent the negative effects of emotional labor. These trainings should be implemented regularly and continuously, and they should include creative drama, simulation, role play methods. In-service training should be provided for the neonatal nurses in order to increase their awareness on neonatal palliative care, and to teach them basic elements of care. Guidelines should be developed to guide the palliative care specific to the newborns. Necessary institutional arrangements should be made in the environment and working conditions of NICU in order to ensure the provision of effective and qualified care services.

\section{ETHICAL DECLARATIONS}

Ethics Committee Approval: Permission was obtained from each institution where the study was conducted, and approval was obtained from the Ethics Committee of the Faculty of Medicine, Ondokuz Mayis University (Date: 26.12.2019, Decision No: B.30.2.ODM.0.20.08/828-1043).

Informed Consent: The nurses who agreed to participate were informed about the purpose and context of the study, and their consent was taken via an informed consent form. Then, a questionnaire was distributed to them. Confidentiality of the participants was ensured by making the survey anonymous. All data were used for scientific purposes only, and not shared with anyone or for commercial purposes. All participants had the opportunity to withdraw from the study at any time.

Referee Evaluation Process: Externally peer-reviewed.

Conflict of Interest Statement: The authors have no conflicts of interest to declare.

Financial Disclosure: The authors declared that this study has received no financial support.

Author Contributions: All of the authors declare that they have all participated in the design, execution, and analysis of the paper, and that they have approved the final version.

Acknowledgement: The authors thank all neonatal nurses who helped them in performing this study.

\section{REFERENCES}

1. Ünal S, Zenciroğlu A. Palliative care for newborn infant. Turkish J Ped. Disease 2016; 10: 149-55.

2. Akay G. Turkish validity and reliability of the neonatal palliative care attitude scale. Masters Thesis. Erzurum, Turkey, 2017; 4-18.

3. Kilcullen M, Ireland S. Palliative care in the neonatal unit: Neonatal nursing staff perceptions of facilitators and barriers in a regional tertiary nursery BMC Palliative Care 2017; 16.

4. Cricco-Lizza R. The need to nurse the nurse: emotional labor in neonatal intensive care Qual. Health Res2014; 24: 615-28.

5. Mendel TR. The use of neonatal palliative care: Reducing moral distress in NICU nurses. Journal of Neonatal Nursing 2014; 20: 290-3.

6. Özçelik H, Aksoy F, Sönmez E, Fadıloglu Ç. Attitudes to death of nurses in Turkey and factors affecting them. Hospice \& Palliative Med Inter J 2018; 303-9.

7. Değirmenci Öz S, Baykal Ü. Nurses' emotional labor behavior and factors affecting. Florence Nightingale J Nurs 2018; 26: 1-10.

8. Chou H, Hecker R, Martin A. Predicting nurses' well-being from job demands and resources: A crosssectional study of emotional labour. J Nurs Manag 2012; 20: 502-11.

9. Cheng C, Bartram T, Karimi L, Leggat S. The role of team climate in the management of emotional labour: implications for nurse retention. J Adv Nurs 2013; 69: 2812-25.

10.Dall'Ora C, Ball J, Recio-Saucedo A, Griffiths P. Characteristics of shift work and their impact on employee performance and wellbeing: A literature review. Inter. J Nurs Stud 2016; 57: 1227.

11.Delgado C, Upton D, Ranse K, Furness T, Foster K. Nurses' resilience and the emotional labour of nursing work: an integrative review of empirical literature. Inter J Nurs Stud 2017; 70: 71-88.

12.Elliott C. Emotional labour: learning from the past, understanding the present. Br J Nurs 2017; 26: 1070-7.

13.Vermaak C, Görgens-Ekermans G, Nieuwenhuize C. Shift work, emotional labour and psychological well-being of nursing staff. J Contemporary Manag Iss 2017; 22: 35-48.

14.Donoso LM, Demerouti E, Hernández EG, Moreno-Jiménez B, Cobo IC. Positive benefits of caring on nurses' motivation and well-being: A diary study about the role of emotional regulation abilities at work. Int J Nurs Stud 2015; 52: 804-16.

15.Yllmaz B, Orak OS. Relationship between emotional labour behavior and psychological symptoms among nurses. J Health Nurs Manag 2020; 7: 187-201.

16. Tahghighi M, Rees CS, Brown JA, Breen LJ, Hegney D. What is the impact of shift work on the psychological functioning and resilience of nurses? An integrative review. J Adv Nurs 2017; 73: 2065-83.

17.Lee M, Jang KS Nurses' emotions, emotional labor, and job satisfaction. Int J Workplace Health Management 2020; 13: 1631 .

18.Gülşen M, Özmen D. The relationship between emotional labour and job satisfaction in nursing. Int Nurs Rev 2020; 6: 145-54.

19.Özkol Kılınç K, Bayrak B, Özkan ÇG, Kurt Y, Öztürk H. Assessing nurses' emotional labor levels. J Academic Res Nurs 2020; 6: 309-16.

20.Baksi A, Durmaz Edeer A. Investigation of the relationship between emotional labor and general health status of intensive care nurse. J Hacettepe Uni Fac Nurs 2020; 7: 130-7.

21.Grandey AA. Emotion regulation in the workplace: a new way to conceptualize emotional labor. J Occup Health Psychol 2000; 5: 95-110. 
22.Brotheridge CM, Lee RT. Development and validation of the emotional labour scale. J Occu Organizational Psychology 2003; 76: 365-79.

23. Oral L, Köse S. A research on phsicians' use of emotional labor and the relationship between their job satisfaction and burnout levels. Suleyman Demirel Uni. J Faculty Economics Admin. Sci 2011; 16: 463-92.

24.Kain V, Gardner G, Yates P. Neonatal palliative care attitude scale: Development of an instrument to measure the barriers to and facilitators of palliative care in neonatal nursing. Pediatrics 2009; 123: 207-13.

25.Chen $\mathrm{CH}$, Huang LC, Liu HL, Lee HY, Wu SY, Chang YC. To explore the neonatal nurses' beliefs and attitudes toward scaring for dying neonates in Taiwan. Mat Child Health J 2013; 17: 1793801 .

26.Azzizadeh Forouzi M, Banazadeh M, Ahmadi JS, Razban F Barriers of palliative care in neonatal intensive care units. Am J Hosp Palliat Care 2017; 34: 205-11.

27. Shi H, Shan B, Zheng J, Peng W. Knowledge and attitudes toward end-of-life care among community health care providers and its influencing factors in China: A cross-sectional study. Medicine (Baltimore) 2019; 98: e17683.

28. Melvin CS. Historical review in understanding burnout, professional compassion fatigue, and secondary traumatic stress disorder from a hospice and palliative nursing perspective. J Hospice Palliat Nurs 2015; 1: 66-72.

29.Ingebretsen LP, Sağbakken M. Hospice nurses' emotional challenges in their encounters with the dying. Int J Qualitative Stud Health Well-Being 2016; 11: 31170 .

30.Lewis S. Exploring NICU nurses' affective responses to end-oflife care. Advances in Neonatal Care 2017; 17: 96-105.

31.Broom A, Kirby E, Good P, Wotton J, Yates P, Hardy J. Negotiating futility, managing emotions: Nursing the transition to palliative care. Qual Health Res 2014; 25: 299-309.

32. Wright V, Prasun MA, Hilgenberg C. Why is end-of-life care delivery sporadic? A quantitative look at the barriers to and facilitators of providing end-of-life care in the neonatal intensive care unit. Adv Neonatal Nurs 2011; 11:29-36

33. Karlsson M, Kasén A, Wärån-Furu C. Reflecting on one's own death: The existential questions that nurses face during end-oflife care. Palliat Support Care 2017; 15: 158-67.

34. Kassa H, Murugan R, Ababa A, Zewdu F, Hailu M. Assessment of knowledge, attitude and practice and associated factors towards palliative care among nurses working in selected hospitals, Addis Ababa, Ethiopia. BMC Palliat Care 2014; 13: 6.

35. Kalogeropoulou M, Vikia E, Kostagiolas AP, Niakas D. Assessment of knowledge and associated factors towards palliative care among Greek nurses. World J Soc Sci Res 2016; 3: 381-95.

36. Ryan L, Seymour J. Death and dying in intensive care: Emotional labour of nurses. End of Life J 2013; 3: 1-9.

37.Funk LM, Peters S, Roger KS. The emotional labor of personal grief in palliative care: balancing caring and professional identities. Qualit. Health Res 2017; 27: 2212-21.

38. Brighton LJ, Selman LE, Bristowe K, Edwards B, Koffman J, Evansa CJ. Emotional labour in palliative and end-of-life care communication: A qualitative study with generalist palliative care providers. Patient Educ Coun 2019; 102: 494-502.

39. Kinman G, Leggetter S. Emotional Labour and Wellbeing: What protects nurses? Healthcare (Basel) 2016; 4: 89. 